\title{
Minas e a aclamação de D. João VI no limiar da formação do Estado-Nação brasileiro: memórias, conflitos e sedições
}

\author{
Minas and the acclamation of D. João VI \\ at the threshold of Brazilian National State: \\ memories, conflicts and rebellions
}

José Carlos Barreiro

Os viajantes estrangeiros que passaram pelo Brasil ao longo dos vários momentos de sua história deixaram registros minuciosos sobre aspectos múltiplos da vida social, econômica e política do país. Contudo, ao longo de quase todo o período colonial, a presença de estrangeiros em solo brasileiro foi muito limitada. A interdição portuguesa à entrada no Brasil de visitantes de outros países, vigente desde 1591, cessaria apenas com a abertura dos portos decretada em 1808

José Carlos Barreiro é professor titular de História do Brasil do Departamento de História da Unesp, Campus de Assis (jcbarr@assis.unesp.br).

Artigo recebido em 2 de fevereiro e aprovado para publicação em 6 de setembro de 2012.

Est. Hist., Rio de Faneiro, vol. 25, n 50, p. 370-388, julho-dezembro de 2012. 
pelo príncipe regente $\mathrm{D}$. João, de Portugal. Somente a partir de então se intensificou a vinda de estrangeiros ao Brasil, configurando-se uma espécie de redescoberta e revisitação do país pelos viajantes.

Entre os viajantes estrangeiros que percorreram o Brasil nesse período destacam-se os alemães Spix e Martius, não só pelo imenso inventário científico que fizeram da natureza local, mas também pelos ricos depoimentos que colheram da cultura e da sociedade brasileira da época (Spix \& Martius, 1976). Tais depoimentos incluem uma minuciosa descrição das festas de aclamação do rei $\mathrm{D}$. João VI, em 1818, realizadas no arraial de Tejuco (atual Diamantina), na região das Minas, que serão objeto mais imediato de nossas preocupações neste artigo.

A igreja matriz de Santo Antônio, edificada em uma praça, foi o centro em torno do qual se desenvolveu o arraial de Tejuco, com a construção, desde meados do século XVIII, das principais casas, sobrados e solares dos intendentes do ouro e diamante. Tejuco era uma aglomeração que não poderia ser considerada pequena para os padrões da época. No terceiro quartel do século XVIII o arraial contava com quase 510 casas dispostas em 19 ruas e 7 becos, habitadas por um total de 884 moradores livres. Quando o viajante francês Saint-Halaire por lá passou, em inícios do século XIX, o núcleo urbano possuía por volta de 6 mil habitantes e cerca de 800 casas. Ressaltou ele a existência de um ambiente de luxo e riqueza, movimentado por um comércio cujas lojas estavam repletas de objetos importados, entre os quais louças da Inglaterra e da Índia. Saint-Hilaire ressaltou ainda que o ambiente intelectual em Tejuco era o mais fértil da capitania de Minas, cuja elite instruída sabia falar fluentemente o francês, sua língua materna. Havia em Tejuco uma ópera onde eram encenadas peças populares da época. Alguns artistas, como músicos e pintores, mereceram destaque pelo refinamento da arte que apresentavam.

No levantamento de alguns inventários de homens importantes do arraial foram encontradas bibliotecas com muitos volumes de livros escritos por filósofos iluministas e escritores europeus. Eram inúmeros os estudantes de Tejuco formados em universidades do exterior. No ano de 1782, quase a metade dos candidatos mineiros a vagas na Universidade de Coimbra procedia de Tejuco e de Serro do Frio, o que explica a vida intelectual relativamente movimentada do arraial. ${ }^{1}$ Por essa importância econômica, social, política e cultural, o arraial de Tejuco não poderia ficar fora das festividades de aclamação do rei D. João VI.

Os rituais e as festas cívicas, religiosas e populares não eram novidade no Brasil e ocorreram durante quase todo o período colonial. Os bragantinos nunca perdiam a oportunidade de realizar grandes festejos por ocasião da aclamação de monarcas, do nascimento de príncipes, aniversários e casamentos de membros da família real. Os festejos eram realizados em Portugal, mas não deixavam de ter sua versão alegre e barulhenta no Brasil. Lembremos, a título de exemplo, a 


\section{José Carlos Barreiro}

grande pompa de que se revestiu na colônia o anúncio, em 1793, de uma festa em comemoração do aniversário da princesa da Beira, depois D. Maria I, rainha de Portugal. $^{2}$

Contudo, os festejos de aclamação descritos por Spix e Martius revestem-se de características singulares em relação aos que ocorriam anteriormente, por estarem articulados a profundas modificações históricas em curso naquele momento. Com a transferência da Corte, o Rio de Janeiro, cidade-sede do Império Luso-Brasileiro, começou a se apresentar como centro de um complexo político-administrativo que abrigaria posteriormente a capital do Brasil independente (Gouvêa, 2005: 707-752). Ademais, havia outra grande novidade: o rei não estava mais em Portugal, e sim no Brasil. A partir daquele momento os habitantes do Brasil passariam a viver na contingência de introjetar e acostumar-se à ideia de ter um rei à frente da cena política. A criação de rituais em que se teatralizava um grande jogo simbólico no qual a realeza aparecia como personagem frequen$t^{3}$ expressava, entre outros aspectos, tal exercício de dominação política.

As cerimônias de aclamação do rei D. João VI configuravam-se como uma grande oportunidade para que a monarquia bragantina exibisse poderio e grandeza, num momento em que encontrava sérias dificuldades para manter as colônias sob seu domínio político e econômico. Mas ao mesmo tempo apresentaram-se também como o primeiro momento da construção de um capital simbólico fundamental, aproveitado pelo Estado brasileiro a partir de 1822 para a criação de uma peculiar tradição monárquica, adaptada aos costumes dos trópicos.

As cerimônias aconteceram nas principais províncias do Brasil, mas no Rio de Janeiro, sede do aparato de Estado português naquele momento, ganharam, como era natural, a dimensão de um espetáculo que se assemelhava às pompas das grandes celebrações reais portuguesas. A vinda recente de artistas da Missão Francesa constituiu-se numa feliz coincidência que permitiu o engajamento de Debret, Grandjean de Montigny e Auguste Marie Taunay na construção dos monumentos comemorativos. Um templo consagrado a Minerva, com $17,60 \mathrm{~m}$ de altura e $63,80 \mathrm{~m}$ de fachada, foi construído à beira do cais. Mais para $\mathrm{o}$ centro do largo do Paço foi construído um arco do triunfo, com 13,20m de altura e 15,40m de largura, com colunas, estátuas e alegorias de toda ordem. Um obelisco real erigia-se no centro da praça, e era também ali que a multidão esperava pela saída do rei do interior do palácio, de onde, ostentando trajes e objetos carregados de significações simbólicas, faria o juramento real. ${ }^{4}$

Assim, as festividades de aclamação realizadas no Rio de Janeiro, lugar central e estável identificado com a soberania pública, espelhavam a autoridade política e o equipamento simbólico da monarquia. Todavia, realizar o cerimonial apenas no Rio de Janeiro não assegurava tudo, principalmente diante da necessidade de dominação sobre um território em permanente ameaça de desintegração 
como foi o Brasil ao longo de todo o primeiro reinado. Seria necessário que o soberano se deslocasse para várias partes do reino, principalmente para as regióes onde havia sérios conflitos políticos. Porém a própria natureza da cerimônia de aclamação impossibilitava a realização do espetáculo físico da soberania do rei, minuciosamente ritualizado, como ocorreu no Rio de Janeiro. Não sendo isso possível, o Estado precisava acionar seus equipamentos administrativos e suas instituições para que a autoridade soberana se fizesse sentir em lugares distantes, mesmo sem a presença do rei. ${ }^{5}$ Foi esse o caso das cerimônias de aclamação do rei ocorridas em Tejuco simultaneamente às que se realizavam no Rio de Janeiro em fevereiro de 1818.

Sem a presença do soberano, as festividades foram realizadas com a imagem do rei D. João VI apresentada de maneira grandiosa ao numeroso público presente e acompanhada de danças, teatros e várias outras exibições. A organização das cerimônias esteve a cargo de Manuel Ferreira da Câmara, autoridade política de maior poder em Tejuco naquele momento. Nomeado intendente geral das Minas Gerais e Serro do Frio em 1807, o intendente Câmara, como era conhecido, revelou-se um quadro à altura da relevância da tarefa legada pelo equipamento administrativo do Estado. De fato, Ferreira da Câmara, embora nascido na capitania de Minas Gerais, realizara seus estudos na Universidade de Coimbra, pertencera à Academia Real das Ciências de Lisboa e empreendera uma viagem científica pelos principais centros de mineração da Europa central e setentrional. Seu processo de formação e especialização científica transformou-o em um personagem importante no âmbito da política de renovação cultural-científica do governo de D. Maria I. Tal política tinha como principal objetivo a criação de um novo corpo de funcionários ilustrados que forneceria pessoal à burocracia para servir ao reino português e suas colônias. ${ }^{6}$

Foi nesse contexto que os viajantes Spix e Martius, passando pela região, conheceram Ferreira da Câmara, assistiram e descreveram as festividades de aclamação do rei D. João VI em virtude da morte, em 1816, da rainha D. Maria I. Ambos eram alemães e vieram ao Brasil acompanhados de outros cientistas, contratados pelo imperador Francisco I, pai da arquiduquesa D. Leopoldina, que à época se preparava para casar-se com D. Pedro de Alcântara, herdeiro da Coroa portuguesa.

Spix e Martius permaneceram no país de 1817 a 1820 e percorreram nesse período várias localidades brasileiras, entre elas Rio de Janeiro, São Paulo, Minas Gerais, Bahia, Pernambuco, Maranhão, Pará e Amazonas. Mesmo referindo-se a maior parte de suas observações à flora e à fauna, é impossível ignorar a relevância das anotações que deixaram relativas às características peculiares das principais cidades brasileiras e ao caráter de sua população. Em suas avaliações sobre as possibilidades da constituição de um Estado-Nação no Brasil, eles fo- 


\section{José Carlos Barreiro}

ram céticos e pessimistas quanto à contribuição dos negros e algumas vezes esperançosos em relação a outros segmentos sociais pobres da população.

A problemática do espaço urbano esteve na pauta de observações de Spix e Martius sobre o Brasil, pauta esta orientada, entre outras questões, pela problemática urbana e sanitária europeia em discussão na Europa à época em que visitaram o Brasil. ${ }^{7}$ Pensar essas questões era indispensável para que pudessem pensar também a organização de um espaço político que se constituísse em arcabouço institucional sólido para a construção da nova realidade brasileira. Assim, não escaparam a seus olhares, por exemplo, aspectos como o ritmo, o traçado das ruas, as pessoas, a movimentação dos portos, as operações manuais de carga e descarga, os vendedores ambulantes e o som da música que acompanhava o trabalho dos negros.

Nos discursos de Spix e Martius (1976: 42, vol. 1) sobre a população dos arraiais, vilas e cidades por onde passavam, as representações construídas sobre o negro são particularmente reveladoras de como, no pensamento deles, a modernidade teria que se firmar sobre a selvageria da América. Logo que desembarcaram dos navios, expressaram a desconfortável sensação de se encontrarem em algum estranho continente do mundo, principalmente observando a imensa variedade de negros e mulatos que perambulavam por toda a parte. Para eles, aqueles homens seminus, de natureza bruta e inferior, feriam a sensibilidade de qualquer europeu que tivesse acabado de deixar os costumes delicados e as fórmulas obsequiosas de sua pátria. ${ }^{8}$

As características de diário de viagem e o tempo de que dispunham os viajantes para efetuar seus registros determinavam muitas vezes que eles se limitassem a descrever aquilo que consideravam essencial. Mas nem sempre o problema era o tempo para o registro, e sim a relevância que este ou aquele fato adquiriam diante do filtro cultural deles próprios. Isto revela o quanto o exercício de transpor para a escrita e eternizar um acontecimento em forma de lembrança (Le Goff, 1984: 11-50) transformava os viajantes em senhores da memória e do esquecimento em relação àquilo que observavam no Brasil. Sem dúvida, seus registros seletivos dos vários aspectos da sociedade brasileira passavam sempre por manipulações conscientes ou inconscientes que a censura do imaginário da modernidade exercia sobre a memória individual ou coletiva daquele período histórico. Diante disso, complementar tais descrições com informações de outras fontes torna-se quase sempre imperioso para o conhecimento do fenômeno em sua dimensão maior.

Recorremos, então, às anotações do memorialista Joaquim Felício dos Santos (Santos, 1976), que também descreveu as celebrações de Tejuco e a aclamação de D. João VI, para complementar e auxiliar na compreensão que Spix e Martius tiveram daquelas festividades. Felício dos Santos nasceu em 1828 na 
Vila do Príncipe, portanto, na mesma região de Tejuco, alguns anos depois que por lá passaram Spix e Martius. Nas arcadas do velho Convento do Largo de São Francisco, em São Paulo, Felício dos Santos foi contemporâneo de José de Alencar, considerado o maior romancista do período romântico brasileiro. Como Alencar, formou-se também em Direito e militou ativamente na política e no jornalismo. Em 1850 voltou para Tejuco, já então denominado Diamantina. A reunião de artigos publicados no periódico O fequitinhonha, do qual foi redator principal, resultou em seu livro Memórias do Distrito Diamantino, com informações preciosas sobre as festividades de Tejuco.

O que Spix e Martius observaram em Tejuco sobre as cerimônias de aclamação e o material posteriormente reunido por Joaquim Felício dos Santos sobre a mesma questão formam um rico arsenal de figurações estéticas, cuja decodificação pode se constituir em estratégia privilegiada para o entendimento da criação, naquele momento, de mitos que dariam sustentação e direção à nova realidade a ser inaugurada no Brasil: a de sua transformação em Estado independente, porém nos moldes concebidos pela metrópole portuguesa. Desenvolveremos aqui a ideia de que tais objetivos dependiam da afirmação do prestígio político do rei diante do povo e das elites regionais brasileiras, quase sempre divergentes quanto a seus interesses específicos (Graham, 2001: 17-56). Isso envolvia muitas vezes um conflito de memórias entre os significados simbólicos das celebrações reais e os diversos imaginários coletivos regionais que se criaram ao longo da dominação colonial portuguesa. As celebrações de aclamação do rei $\mathrm{D}$. João VI ocorridas em Tejuco são apenas um exemplo do caráter específico que elas poderiam assumir em cada região onde eram realizadas. Trata-se, pois, de um desafio dos mais instigantes desenvolver um justificado esforço no sentido de desvendar alguns dos enigmas veiculados pelo vocabulário simbólico daquelas celebrações.

Spix e Martius iniciam a descrição das celebrações mencionando os atores e o povo reunidos e percorrendo as ruas em préstito festivo até chegar à praça onde a apresentação deveria ocorrer. O cortejo era aberto por arautos, espécie de oficiais que nas monarquias do Antigo Regime e da Idade Média faziam as publicações solenes, seguidos do coro de cantores e mais quatro figurões, representando as vastas possessões da monarquia portuguesa. Esses personagens portavam um globo terrestre decorado com os emblemas do europeu, do índio, do negro e do americano, acima do qual estava a imagem de D. João VI. Fechava o préstito um grupo numeroso de rapazes e raparigas vestidos como pastores, trazendo guirlandas de flores com as quais, chegando ao teatro, enfeitavam a imagem do monarca, sob as aclamações do público presente. Tais descrições indicam claramente a vinculação das festividades de Tejuco às principais regras da tradição medieval europeia. Porém, na continuidade das descrições feitas por Spix e Mar- 


\section{José Carlos Barreiro}

tius, vemos que as culturas locais eram também partes constitutivas das festividades. Estabelecia-se, pois, um diálogo entre a tradição europeia de corte e a formação cultural multiétnica do Brasil.

Segundo os viajantes Spix e Martius, depois os coros executaram danças portuguesas, das Índias Orientais e dos negros, e no intervalo apareceram quatro arlequins "que divertiam a numerosa assistência com pulos bizarros, parodiando os desajeitados gestos dos selvagens americanos" (Spix \& Martius, 1976: 39, vol. 2). Para representar a época cavalheiresca da Europa foi exibida a simulação do tradicional combate entre mouros e cristãos, mais conhecido como cavalhada. Incorporados às tradições locais, sempre que esses folguedos eram apresentados provocavam fortes emoções nos espectadores. Spix e Martius fizeram uma descrição minuciosa e francamente elogiosa da exibição.

Como parte das festividades de aclamação, os negros também apresentaram seus festejos. Ao mesmo tempo que homenagearam D. João VI com suas congadas, aproveitaram a oportunidade para escolher o rei e a rainha de sua comunidade. Contudo, em relação aos festejos apresentados pelos negros, em que foram escolhidos o rei do Congo e a rainha Xinga, os viajantes não foram nada simpáticos. Tudo parecia muito ridículo para eles, desde as imagens dos santos católicos tradicionais pintados de preto, até a banda de música com seus componentes vestidos com roupas de cores berrantes, rotas e cheias de buracos. Enfeitados com grandes penas de avestruz saíam eles ao som de pandeiros, tambores, pífanos, chocalhos, canzás e marimbas.

Enfim, desse diálogo que se estabelecia entre o estilo europeu e os multifacetários elementos nacionais, Spix e Martius pareciam compreender apenas o primeiro. De tudo o que assistiram sobre o espetáculo dos negros, restou-lhes principalmente a lembrança da algazarra infernal que faziam com seus rústicos instrumentos, os pulos e cabriolas, as singulares caretas e abjetas posições, tudo formando um espetáculo tão bizarro que imaginaram estar diante de um bando de macacos (Spix \& Martius, 1976: 40-41, vol.2).

As festividades de Tejuco, segundo Felício dos Santos, foram divulgadas na Bahia em 1819, por meio de um folheto impresso que foi por ele amplamente utilizado na elaboração de seu livro. Infelizmente Felício dos Santos não traz maiores informações a respeito de tal folheto. Sabemos, contudo, que o poder monárquico possuía meios materiais e humanos para divulgar através de folhetos as diversas festividades de aclamação de D. João VI por diversas regiões do Brasil. Lembremos que nos porões do navio Medusa, que trouxe a família real para o Brasil, veio encaixotada uma gráfica novinha em folha que assumiria o papel de Impressão Régia, funcionando a partir de 13 de maio de 1808, data de sua criação. A gráfica da Impressão Régia inaugurou seus trabalhos estampando em um folheto de 27 páginas a relação dos despachos publicados no aniversário do 
príncipe regente. Certamente a Impressão Régia continuou desempenhando no Brasil o papel que desempenhavam os folhetos (impressos e manuscritos) produzidos em Portugal entre os séculos XVI e XVIII, de meios persuasivos de exercer o poder político na época moderna (Monteiro, 2009: 203).

Reproduções dessa natureza eram importantes instrumentos para aumentar e ampliar para a maior parte possível do território a visibilidade do rei e de eventos como os que ocorriam em Tejuco. Assim, o livro de Felício dos Santos, apoiado nesse folheto, amplia e complementa as informações de Spix e Martius sobre aquelas festividades. No livro aparece, por exemplo, a descrição da iluminação geral da cidade iniciada no dia 28 de maio de 1818, com duração de seis dias. A iluminação deu mais ênfase à casa de Ferreira da Câmara, que se distinguia entre os palacetes públicos e residências dos homens influentes de Tejuco. Felício descreve a apresentação solene de um $T e$ Deum, de uma tragicomédia, além das cavalhadas e dos banquetes. Já Spix \& Martius descrevem as seis janelas do palacete de Ferreira da Câmara, onde foram distribuídos quadros com dísticos explicativos em latim de divindades que representavam o Despotismo, a Aristocracia, a Monarquia, a Democracia, a Anarquia, a fustiça, a Clemência, o Reino Unido, o Casamento e o Amor Conjugal (Spix \& Maritus, 1976: vol.2, 235-238).

Não é tarefa simples fazer a leitura dos retratos, peças de teatro, pinturas e esculturas que compuseram as festividades, pois elas pertenciam a outro tempo e a outro momento da formação cultural brasileira. Para os leitores atuais há um considerável risco de efetuar julgamentos anacrônicos em relação às festividades de Tejuco, desconsiderando as modificações nas mentalidades e nos valores havidas desde então até nossos dias. Por isso não negligenciamos as descrições que delas fizeram os próprios contemporâneos. ${ }^{9}$ Foi indispensável, contudo, perscrutar as intenções que motivavam todas aquelas apresentações para não correr $o$ risco de ficar com o que as fontes diziam sem procurar revelar e entender o que elas de fato escondiam.

Por exemplo, as referências ao passado, sobretudo aos deuses e heróis clássicos, que apareceram ao longo de todas as festividades, eram alegorias que deveriam ser entendidas como referências indiretas aos conflitos e à organização política vivida naquele presente. E os espectadores eram treinados para construir esse tipo de entendimento. Em cada um dos quadros distribuídos pelas seis janelas do intendente Ferreira da Câmara havia inscrições explicativas em latim. Elas davam eficácia aos retratos, pois instruíam os espectadores sobre o modo de interpretar o que viam. Para cada uma das referências que apareciam nos quadros havia uma explicação no folheto, que foi reproduzida por Felício dos Santos em seu livro.

Alguns dos emblemas dos quadros veiculavam mensagens referentes a formas de governo com as quais Portugal não se identificava ou que até mesmo 


\section{José Carlos Barreiro}

abominava. O quadro Despotismo explicava ao público assistente que aquela não era uma boa forma de governo. Para dizer isso retratava um nobre e austero muçulmano portando em uma das mãos um cetro de ferro e tendo a seus pés aquele a quem dominava com brutalidade. A crítica era evidente, pois o déspota era muçulmano (portanto, não cristão). Ademais, o cetro, um dos símbolos do poder real, era confeccionado com material não nobre.

Os quadros Democracia e Anarquia veiculavam mensagens com endereços certos. Formavam uma clara advertência ao povo sobre os perigos das insurreições que ocorriam no Brasil daqueles tempos e de épocas anteriores, criando uma situação política de descrédito em relação aos movimentos de contestação da época. Na descrição de Felício dos Santos, a Democracia era representada por uma donzela sedutora em seu porte e alinho, suspensa nos ares com dois braços abertos, designando os extremos dessa forma de governo. A seu lado estava o monstro da inveja, tendo sob seus pés um monte de cobras e víboras escondidas entre espinhos. Acima de sua cabeça via-se a Razão fugindo. A Anarquia apresentava-se como advertência ainda mais severa às cerca de seis a oito mil pessoas que assistiam às festividades. Estava personificada sob a forma de uma fúria desalinhada e sem compostura. Por cima de sua cabeça se via a paz a fugir e a seu lado apareciam searas em chamas. Abaixo estavam as belas artes em ruína e o compasso quebrado. Aos seus pés via-se o monstro da discórdia, que reina quando um povo se acha em tão desgraçada situação, ameaçando destruir tudo. Todas as contestações a que o governo central era submetido pelos movimentos insurrecionais da época deram ensejo a que nas festividades de Tejuco a representação da deusa da fustiça fosse feita de forma muito singular. Além da balança que a distinguia, tinha ela também a espada cravada na boca do monstro da insurreição, castigando assim a perigosa liberdade de falar e seduzir, que tanto mal fazia aos governos estabelecidos.

Às noites havia apresentações de tragicomédias na praça de Santo Antônio. A que foi descrita por Spix e Martius, considerada por eles sem muita importância, recebeu o título $A$ noiva reconquistada. O pano de cena da peça foi pintado, ainda segundo Spix e Martius, por um brasileiro, que, embora sem estudos, usou um colorido adequado e desenvolveu com muito gênio as proporções, o que para os viajantes já prenunciava certo desenvolvimento artístico no Brasil. Nele estava pintada uma figura representando o gênio do Brasil, que pisava a hidra da desunião e ao mesmo tempo oferecia aos habitantes um molho de espigas. Felício dos Santos referiu-se à apresentação da peça $O$ salteador exaltando o bom desempenho dos atores e principalmente do casal que representou os personagens $\mathrm{Ca}$ mila e o Capitão dos Ladrões. O cenário para a apresentação da peça compunha-se em sua fachada de um arco da ordem jônica, coroado com armas do Reino Unido. $\mathrm{O}$ pano de cena da peça era uma cópia do quadro Clemência, afixado em uma 
das janelas da casa do intendente Ferreira da Câmara. Portanto, as festividades de aclamação de D. João VI, que ocorreram em várias partes do Brasil, incluíram, como podemos constatar no caso de Tejuco, meios de divulgação os mais diversos, veiculando mensagens consideradas necessárias para o momento político que vivia o Brasil. Não faltavam estátuas e retratos do próprio rei, a representação de várias divindades, a impressão de folhetos e pinturas de panos de cena ajudando a compor as narrativas das tragicomédias apresentadas. As mensagens transmitidas misturavam palavras, imagens e ações para as quais colaboravam roteiristas, pintores e coreógrafos.

Toda a complexa alegoria acima descrita envolvia a tematização da organização do poder em vários planos. No âmbito das relações de Portugal com seu império colonial, as descrições de Spix e Martius são bastante esclarecedoras. A autoridade soberana do rei encarnada pela estátua representando a figura ao mesmo tempo mortal e imortal de D. João VI, situada acima do globo terrestre transportado por quatro figurões, evocava a centralização absolutista e a teorização da origem extra-social do poder baseada no direito divino. O olhar do rei está acima dos olhos dos espectadores, sublinhando sua posição superior. Para glorificar o rei, o cortejo realiza-se de forma triunfal, como faziam os romanos da era clássica, quando a realeza e seu cortejo adentravam as cidades. A exibição de todas as possessões portuguesas representadas por figurões e emblemas fazia todo sentido num momento em que as preocupações se voltavam para promover a soldagem do agonizante império português. A fraternidade e igualdade entre europeus, negros, americanos e índios parecia fundamentar uma unidade e uma identidade que encontravam sua figuração no corpo do rei. Se, em outras partes, essa representação estava intensamente abalada desde fins do século XVIII, em virtude do desenvolvimento da ideia do individualismo e do progresso, aqui, essas mesmas ideias davam sustentação à imagem teológico-política de um poder identificado com a sociedade do Antigo Regime.

Outro plano de organização do poder aparece também, de forma emblemática, quando as alegorias são analisadas no âmbito dos conflitos e ressentimentos entre interesses metropolitanos e complexos e interesses brasileiros diferenciados, tanto no que respeita à região das Minas quanto ao Brasil como um todo. Essas alegorias aparecem, sobretudo, nas peças de teatro descritas por Spix e Martius e por Felício dos Santos. A peça tragicômica $A$ noiva reconquista$d a$ não teve seu conteúdo inteiramente especificado nas anotações de viagem de Spix e Martius. Os viajantes nos deram a conhecer apenas o título da peça e a descrição da pintura de seu pano de cena. $\mathrm{O}$ mesmo pode ser dito da peça $O$ salteador, descrita por Felício dos Santos. Contudo, embora escassas, essas informações sugerem de forma indiciária algumas chaves para sua decodificação. $\mathrm{O}$ 
título $A$ noiva reconquistada e os personagens Camila e o Capitão dos Ladrões de $O$ salteador indicam que o mito central de ambas as peças é o do casal. $\mathrm{O}$ mito do casal aparece também, e com muita transparência, no quadro afixado na quarta janela da casa do intendente Ferreira da Câmara, em que se estampava o emblema do Amor conjugal, representado por dois corações que ardiam em uma mesma pira, e por um casal de pombos que se afagavam. Em outra janela, por fim, estampa-se mais uma figuração mitológica do tema do casal: ao Reino Unido seguia-se o emblema do casamento, no qual a Religião unia um lindo par. Por cima da Santa Cruz, distintivo da Religião, viam-se juntas as armas do Império Austríaco e as do Reino Unido. A presença simbólica das armas do Império Austríaco entrelaçadas às do Reino Unido devia-se ao casamento do príncipe D. Pedro com a princesa Leopoldina da Áustria, cujo contrato de núpcias fora contraído em 20/11/1816.

O mito do casal é muito antigo, mas capaz de renovações vigorosas. Aparece, nesse período, na composição da Flauta mágica de Mozart e na continuidade dessa ópera que Goethe tentará encaminhar (Starobinski, 1988: 132-151). No plano interno, o mito do casal emerge como uma das matrizes mais fundamentais da formação da nação. ${ }^{10}$ Nos termos em que aparece nas peças e no quadro da janela, sugere sempre a busca da felicidade através da realização de um par. Se tomarmos a idéia de reconquista trazida no título da peça $A$ noiva reconquistada poderemos observar o quan to o tema da felicidade está articulado ao tema do poder. Trata-se de um poder que não é de forma nenhuma derrisório, porque não supõe a conquista da felicidade em um nível elementar, com o objetivo de satisfação imediata. Ao contrário, a conquista da felicidade do casal envolve, por parte do herói, a dura luta pela reconquista da noiva perdida. A partir do que é tematizado no pano de cena pode-se concluir que a felicidade do casal implica um verdadeiro rito iniciático em que o herói deve enfrentar e derrotar o monstro. É o que comentam Spix e Martius, sobre o pano de cena: o gênio do Brasil está pisando a hidra da desunião. Uma vez cumprida a tarefa de matar a hidra, como fez Hércules em um de seus doze trabalhos, nada mais haveria que pudesse atrapalhar a união feliz entre Portugal e Brasil. O ato final da morte da hidra não é senão o limiar de uma longa viagem em que o herói, caminhando em direção à verdade, descobre progressivamente a voz da consciência. Trata-se de uma simbólica bastante utilizada pelo pensamento das Luzes, em que a caminhada paciente da não razão (animal, errante) transforma-se em razão e senhora de seu próprio poder (Starobinski, 1988: 138)

A referência ao herói mítico da Grécia Antiga e à hidra que aparece na peça apresentada em Tejuco vem dos primórdios do desenvolvimento capitalista. A era moderna, marcada pelo surgimento do movimento neoclássico, quer redescobrir a simplicidade na arte e no pensamento e colocá-la em oposição ao des- 
perdício de força do estilo barroco e rococó tão ao gosto da decadente aristocracia europeia. Através do movimento neoclássico, a sociedade da época retraça a vida dos gregos, recolhendo dela o que podia ser imitado e submetido a um processo de interpretação e adaptação aos valores cívicos, ao capitalismo e aos Estados nacionais em formação (Starobinski, 1988: 110-112). É o que ocorre, por exemplo, quando os modernos recorrem ao mito de Hércules, o herói que, com a ajuda de seu sobrinho Iolaus, após muita luta, finalmente mata o monstro decepando sua cabeça central e cauterizando o coto com um ramo flamejante. Entre os séculos XVII e XVIII os mercadores, os manufatureiros, os planteurs e os oficiais dos reis de países europeus diziam repetidamente que a construção das rotas comerciais, a implantação das colônias, enfim, a edificação de uma nova economia transatlântica constituía um esforço de proporções hercúleas. Esses feitos envolviam também a organização dos trabalhadores da Europa, da África e das Américas para produzir e transportar ouro e prata, peles de animais, peixes, tabaco, açúcar e manufaturas. Para os gregos, Hércules foi o unificador do estado territorial centralizado, e para os romanos significou uma vasta ambição imperial. Por tudo isso os arquitetos da economia atlântica, ligados ao poder político da era moderna, encontraram em Hércules um símbolo do poder e da ordem. Por outro lado, a hidra aparece como o símbolo antitético de Hércules, trazendo desordem e resistência ao processo de implantação e consolidação dos Estados e da moderna economia capitalista. Ou seja, os trabalhadores pobres sem terra, os funcionários dos reis nas colônias, os soldados, os marinheiros e os escravos africanos atuavam como as numerosas e sempre mutantes cabeças da hidra, desenvolvendo sempre novas formas de tumultos, insurreições e revoluções contra os governantes (Linebaugh \& Rediker, 2000: 1-7; 143-173).

Compreende-se então a presença da hidra na peça $A$ noiva reconquistada. Fartamente presente nas figurações estéticas europeias para caracterizar a grandeza da construção da economia capitalista e as resistências de setores dominados da sociedade a essa construção, a metáfora da hidra, identificada com a presença daquela criatura venenosa nascida de Typhon e Echidna, encontra campo fértil também no Brasil. Ela aparece nas numerosas insurreições e levantes que ocorrem desde fins do século XVIII e que só serão parcialmente controlados por volta de meados do século XIX, com o início do reinado de D. Pedro II. Pouco antes da aclamação de D. João VI (6 de março a 19 de maio de 1817) ocorria o movimento da insurreição pernambucana. Documentos de época se indagam por que a cerimônia de aclamação de D. João VI não se realizou logo após a morte da rainha D. Maria I, como era de se esperar. As próprias fontes indicam que a cerimônia ocorreu tardiamente, apenas em 6 de fevereiro de 1818 no Rio de Janeiro, portanto muitos meses após o seu falecimento. Alimentava-se o temor de que a ocasião fosse aproveitada para a realização de contestações políticas de grupos 


\section{José Carlos Barreiro}

descontentes com o governo (Luccock, 1975: 378), sobretudo rebeldes ligados à insurreição pernambucana (Bernardes, 2006: 204-205), tirando assim o brilho das pompas cerimoniais e a autoridade do próprio rei.

A rebeldia dos que participaram do movimento de 1817 foi identificada por contemporâneos ligados ao poder político da época como obra da terrível criatura. Assim que soube da eclosão do movimento, o coronel Maler, cônsul encarregado dos negócios da França no Brasil, apontou em seu primeiro ofício às autoridades de seu país "o haver a hidra revolucionária conseguido erguer uma hedionda cabeça no Brasil" (Lima, 1996: 496). O mito grego da hidra continuou a ser usado em outros momentos conturbados do início da formação do Estado Independente no Brasil, como em um dos pronunciamentos de Antônio Carlos na Assembleia Nacional Constituinte de 1823, referindo-se ao perigo da "hidra de muitas cabeças", que se manifestava perigosamente naqueles momentos (Souza, 1960: 50).

Há razões óbvias para crermos também que a hidra do pano de cena da peça, que estava sendo morta pelo gênio do Brasil, era uma clara alusão aos inconfidentes mineiros e seu movimento. Os fabricadores de símbolos ligados ao poder político de D. João VI pareciam ter como tarefa principal digladiar-se mais fortemente com a memória coletiva que pairava sobre a população de Tejuco e toda a região que a envolvia. O movimento foi de grande extensão, indo de Vila Rica a Tejuco, daí a São João Del Rei, passando por Borda do Campo. Reuniões aconteceram em distintas localidades de Minas, envolvendo também personagens de São Paulo. Essa amplitude geográfica é um dos diferenciais do movimento em relação aos motins ocorridos na primeira metade do século XVIII. Seu desfecho, ligado que estava à maneira tirânica como a população das Minas era cotidianamente vigiada, fiscalizada e brutalmente castigada pelas autoridades portuguesas, cada vez mais ávidas na cobrança do quinto metropolitano, causou enorme desolação por toda a capitania. O grande abalo ocorreu sobretudo após a prisão e julgamento dos conjurados e a consequente derrota do movimento desfechada com a forma medonha da execução de Tiradentes. Testemunhas oculares daquele acontecimento não deixaram de mencionar a consternação dos habitantes da cidade do Rio de Janeiro diante de execução de tão feia e de tão triste ostentação. Richard Burton, passando pela província em meados do século XIX, registrou o quão vivo ainda permaneciam aqueles acontecimentos na memória de seus habitantes. ${ }^{11}$ Não é de estranhar, portanto, que os artistas e os intelectuais a serviço do rei, que organizaram as festividades da aclamação em Tejuco, o fizessem contrapondo-a à memória popular da região, ainda recente e bastante viva, dos acontecimentos da Inconfidência.

As reuniões dos líderes do movimento ocorriam altas horas da noite em casa de José da Silva e Oliveira, pai do padre Rolim. Embora às reuniões dos inconfidentes concorressem as principais pessoas de Tejuco, apenas o padre Rolim 
foi condenado. Esteve preso em Portugal durante onze anos e meio, tendo regressado depois a Tejuco, onde morreu em 1831 (Santos, 1976: 161-166). Portanto, à época dos festejos da aclamação ocorridos em Tejuco, o padre Rolim, um dos principais líderes do movimento, lá estava vivendo. Havia mensagens evidentes aos que assistiam à peça, segundo as quais a verdadeira liberdade não estava consubstanciada na ação dos inconfidentes, ali investidos da alegoria da hidra. A reconquista da noiva, síntese da realização amorosa do herói, coincidia com a conquista de sua liberdade e poder. Este poder caracterizava-se primeiramente por resultar da capacidade do herói (o Brasil) de se impor sacrifícios, sem os quais sua noiva não seria reconquistada. E em segundo lugar, por se ter investido, ao dominar a hidra da desunião, de uma autoridade eficaz, capaz de impor uma ordem.

A alegoria da hidra articulava-se também adequadamente ao quadro das transformações internacionais da época, pois os Estados nacionais estavam em verdadeiros processos formação, não sem resistências e lutas de setores daquelas sociedades que se opunham àqueles projetos. E a construção de um Estado independente no Brasil anunciava-se, seguindo o curso dos acontecimentos internacionais, de forma inexorável com a crise do sistema colonial e a transferência da corte portuguesa. Assim, eram estratégicam a alegoria da hidra e todas as demais, vinculadas que estavam a projetos de natureza global, pois as festividades de aclamação do rei não ocorriam apenas no Rio de Janeiro, mas também em outras províncias, mesmo sem a sua própria presença. Assim as diferentes regiões poderiam mais facilmente ir se integrando, de forma a efetivamente viabilizar com o tempo a existência de uma totalidade que poderia ser concebida como um Estado unificado.

Os registros daqueles acontecimentos permitiam de fato antever o projeto de construção de um Estado independente no Brasil, porém na forma como os portugueses concebiam tal independência. Por exemplo, a hidra não deveria atrapalhar a feliz união entre Portugal e Brasil. Ou seja, a construção do Estado-Nação no Brasil não deveria ser pensada como a de um Estado independente e em oposição à antiga metrópole portuguesa. Pelo contrário, a nova nação brasileira deveria ser continuadora da tarefa civilizadora iniciada pela colonização portuguesa, como pensaram posteriormente, e de forma hegemônica, os integrantes do Instituto Histórico e Geográfico Brasileiro, fundado em 1838.

Do projeto de Estado e de Nação no Brasil, Spix e Martius definem que os negros ficariam fora por não serem portadores da noção de civilização. Eles aparecem mais de uma vez em seus comentários como seres de natureza bruta e inferior, assemelhados a macacos. ${ }^{12}$ É possível notar na leitura dos viajantes que sua percepção de mundo estava informada por um conceito-chave da teoria hu- 


\section{José Carlos Barreiro}

manista de Rousseau, o de perfectibilidade. Ou seja, a capacidade dos homens de resistir aos ditames da natureza e de se aperfeiçoar. ${ }^{13}$ Os arlequins, que apareciam no intervalo das apresentações, não eram inteiramente civilizados nem tampouco portadores de um poder nos moldes daquele que eficazmente impôs ordem e autoridade, ao dominar a hidra. Os arlequins, permanentemente representados na literatura do século XVIII, simbolizavam ainda uma força, que, embora irreprimível, estava articulada às alegrias mais simples, espontâneas e imediatas. ${ }^{14}$ Aqui, Spix e Martius comentam seus pulos bizarros, imitando gestos dos "selvagens americanos". Os arlequins são então aqueles homens de gozo simples, próximo da natureza, e estão em contato estreito com a animalidade. Tanto quanto os arlequins, a evocação do mito do bom selvagem (Rousseau, 1978: 201-352) também se afigurava de forma emblemática nas festividades. O quadro que representava a Clemência, disposto na sexta janela da casa de Ferreira da Câmara, trazia uma divindade que tinha a seus pés, e de joelhos, um índio a quem ela oferecia a paz em um ramo de oliveira e o trabalho em umas espigas de trigo. Tanto os arlequins, que faziam acrobacias e distribuíam espigas no intervalo das peças, quanto o índio ajoelhado aos pés da divindade e recebendo a sua clemência, são portadores de uma energia que pode ser canalizada na elaboração de dois dos maiores símbolos da civilização: o trabalho e as artes. Os índios, os arlequins e o brasileiro sem estudo que com tanto gênio pintou o pano de cena da peça simbolizam a própria transição possível, a identidade parcial, e ainda rudimentar, que, mediante trabalho, esforço e superação de obstáculo, podiam transformar a potência de sua força em poder, tal qual o personagem que dominou a hidra. Podemos perceber que no conjunto dessas significações míticas da peça e nos comentários de Spix e Martius vai-se delineando uma concepção segundo a qual se reconhece a existência de um povo no Brasil, mas ainda em potencial, ainda arlequinal.

\section{Notas}

1. Grande parte das informações sobre o surgimento e a importância da vida social, cultural e intelectual do arraial de Tejuco foi encontrada em Furtado (2003: 37-43).

2. Para maiores detalhes a respeito do significado desta festa e de outras que ocor- reram no Brasil colonial, sugerimos a leitura de Del Priore (2000).

3. Para o caráter teatral da realeza, a dimensão simbólica de seu poder político, bem como o uso de símbolos e rituais como alicerces do poder no Brasil sob D. Pedro 
II, cf. Schwarcz (1998). Para estudos do tema em questão sobre as monarquias europeias, cf. principalmente Elias (1987) e Burke (1984).

4. Para detalhes da cerimônia de aclamação de D. João VI no Rio de Janeiro, cf. Lima (1996: 605-622). O tema é também repassado por Rodrigo Naves para estudar como ocorreu, a partir da vinda da Missão Francesa, a transposição da arte neoclássica da Europa para o Brasil (Naves, 1996: 59-60).

5. Caberia aqui destacar dois importantes trabalhos que instigam, teoricamente, reflexões sobre a formação do Estado brasileiro e outras experiências de unificação de Estados nacionais: primeiro, o de Jacques Revel sobre o processo secular de constituição de conhecimento, de domínio e unificação do espaço nacional francês sob o controle de um soberano, do século XIII ao XIX; segundo, o estudo de Michel Foucault sobre o processo através do qual ocorreram, entre os séculos XVI e XVIII na Europa, as transições dos Estados subordinados à teoria jurídica do soberano para aqueles guiados pelas teorias da arte de governar. Cf. Revel (1990) e Foucault (1982: 277-293).

6. Para um estudo sobre o processo de formação e especialização científica de Manuel Ferreira da Câmara no contexto de renovação do governo de D. Maria I, cf. Varela (2007: vol. 12, n. 23); para a atuação de Ferreira da Câmara em seus cerca de 15 anos de governo sobre o Distrito Diamantino, cf. Revista do Archivo Público Mineiro, jan. a jun. de 1902:13-21.

7. Desde fins do século XVIII a sociedade europeia passou a viver transformações permanentes, fazendo com que a vigilância da vida do pobre deixasse de ser efetuada apenas por patrões e educadores. Já nas primeiras décadas do século XIX as aglomerações urbanas, os bairros operários de Londres, Manchester e as regiões industriais da França, bem como as casas dos trabalhadores e o ambiente das fábricas, começaram a suscitar preocupações sistemáticas de médicos, filantropos e jornalistas. Diante disso, por exemplo, instituiu-se progressivamente a redefinição do espaço da cidade, com base na sua problematização a partir da chamada questão urbana.

8. A partir da segunda metade do século XVIII o olfato, a percepção auditiva e o olhar passaram a compor de forma decisiva (ao lado da questão urbana e da Ideia Sanitária) um quadro em que a vigilância era um instrumento decisivo de dominação burguesa (Corbin, 1989); para entender a questão do refinamento das práticas sociais como um componente básico das representações dos viajantes estrangeiros, foi bastante esclarecedora a leitura do livro de Ribeiro (1983).

9. Os procedimentos teóricos e metodológicos adotados por Peter Burke para analisar a linguagem alegórica utilizada na construção da imagem pública do rei Luís XIV foram importantes para o entendimento das questões aqui analisadas. Cf. Burke, 1994: 27-49.

10. Os pares Peri e Cecília e Martim e Iracema dos romances $O$ Guarani e Iracema de José de Alencar constituem-se em discursos fundadores da identidade nacional, revestidos de um conteúdo mítico redentor da colonização portuguesa em relação ao Brasil. Para análise e reflexão sobre a desconstrução de tais discursos, cf. Ribeiro, "Iracema ou a fundação do Brasil” (1998: 405-413).

11. As informações sobre a reação da população mineira à devassa e à execução de Tiradentes, bem como os depoimentos colhidos pelo viajante Richard Burton, encontram-se em Carvalho (1990: 58-59).

12. Posteriormente, em texto premiado em 1847 pelo IHGB, von Martius defendeu a ideia segundo a qual o historiador deveria mostrar que a missão do Brasil era realizar a mescla das três raças (branco, índio e negro). Mas na defesa desse argumento o negro 
acabava recebendo muito pouca atenção do autor, fruto da visão que tinha do elemento negro como fator impeditivo do processo de civilização. Cf. Guimarães (1988).

13. Sobre o conceito rousseauniano de perfectibilidade, cf. esclarecimentos e comentários de Schwarcz (1993: 44).

Referências bibliográficas

BERNARDES, Denis. $O$ patriotismo constitucional: Pernambuco, 1820-1822. Recife/ São Paulo: Hucitec/Fapesp, 2006.

BURKE, Peter. $A$ fabricação do rei - a construção da imagem pública do rei Luis XIV. Trad. Maria Luiza X. de A. Borges. Rio de Janeiro: Zahar, 1984.

CARVALHO, José Murilo de. A formação das almas:o imaginário da República no Brasil. São Paulo: Companhia das Letras, 1990.

CORBIN, Alain. Saberes e odores: o olfato e o imaginário social nos séculos XVIII e XIX. Trad. Paulo Neves. São Paulo: Companhia das Letras, 1989.

DEL PRIORE, Mary. História das mulheres: as vozes do silêncio. In: FREITAS, Marcos Cezar (org.). Historiografia brasileira em perspectiva. São Paulo: Contexto, 1998.

- Festas e utopias no Brasil Colonial. São Paulo: Brasiliense, 2000.

ELIAS, Norbert. $A$ sociedade de corte. Trad. Ana Maria Alves. Lisboa: Stampa, 1987.

FOUCAULT, Michel. Microfísica do poder. Trad. Roberto Machado. $3^{\mathrm{a}}$. ed. Rio de Janeiro: Graal, 1982.
14. Papageno, o homem-papagaio, personagem de $A$ flauta mágica de Mozart, e Pulcinella, uma figura de teatro popular, que nas pinturas de Giandomenico Tiepolo traduzem o mundo arruinado da aristocracia europeia do século XVIII, são variações das significações míticas do arlequim.
FURTADO, Junia Ferreira. Chica da Silva e o Contratador dos Diamantes: o outro lado do mito. São Paulo: Companhia das Letras, 2003.

GOUVÊA, Maria de Fátima Silva. As bases institucionais da construção da unidade dos poderes do Rio de Janeiro Joanino: administração e governabilidade no império luso-brasileiro. In: JANCSÓ, István. Independência:História e Historiografia. São Paulo: FAPESP/Hucitec, 2005.

GRAHAM, Richard. Constructing a nation in Nineteenth-Century Brazil, The Fournal of the Historical Society, vol. 1, n. 2-3, 2001.

GUIMARÃES, Manoel Luís Salgado. O Instituto Histórico e Geográfico Brasileiro e o projeto de uma História nacional. Estudos Históricos. Rio de Janeiro, n. 1,1988.

LE GOFF, Jacques. Memória. In: Enciclopédia Einaudi: Memória-História. Lisboa: Imprensa Nacional/Casa da Moeda. 1984

LIMA, Manuel de Oliveira. D. Foão VI no Brasil. $3^{\text {a }}$. ed. Rio de Janeiro: Topbooks, 1996.

LINEBAUGH, P. \& REDIKER, Marcus. The many-headed Hydra. Sailors, slaves, commoners, and the hidden history of the 
revolutionary Atlantic. Boston: Beacon Press, 2000.

LUCCOCK, John. Notas sobre o Rio de $\mathcal{F} a$ neiro e partes meridionais do Brasil. Trad. Milton da Silva Rodrigues. São Paulo/Belo Horizonte: Editora da Universidade de São Paulo/Itatiaia, 1975.

MONTEIRO, Rodrigo Bentes. Folhetos em ordem na Coleção Barbosa Machado. In: ALGRANTI, Leila Mezan \& MEGIANI, Ana Paula. O Império por escrito: formas de transmissão da cultura letrada no mundo ibérico, séculos XVI-XIX. São Paulo: Alameda, 2009.

NAVES, Rodrigo. A forma difícil: ensaios sobre a arte brasileira. $2^{\mathrm{a}}$. ed. São Paulo: Ática, 1996.

REVEL, Jacques. $A$ invenção da sociedade. São Paulo: Difel, 1990.

Revista do Archivo Público Mineiro, jan. a jun. de 1902. Bello Horisonte, Imprensa Official de Minas Geraes.

RIBEIRO, Renato Janine. A etiqueta no Antigo Regime: do sangue à doce vida. São Paulo: Brasiliense, 1983.

- Iracema ou a fundação do Brasil. In: FREITAS, Marcos Cezar (org.). Historiografia brasileira em perspectiva. São Paulo: Contexto, 1998.

ROUSSEAU, Jean-Jacques. Discurso sobre a origem e os fundamentos da desigualdade entre os homens. In: Os Pensadores. $2^{\mathrm{a}}$ ed. São Paulo, Abril-Cultural, 1978.

SANTOS, Joaquim Felício dos. 1976. Memórias do Distrito Diamantino da Comarca do Serro Frio (Província de Minas Gerais). 4ª . ed. São Paulo: Edusp/Itatiaia, 1976.

SCHWARCZ, Lilia Moritz. O espetáculo das raças. São Paulo: Companhia das Letras, 1993.

. As barbas do Imperador: D. Pedro II, um monarca nos trópicos. São Paulo: Companhia Das Letras, 1998.

SOUZA, Octavio Tarquínio de, 1960. Três golpes de Estado. Rio de Janeiro, José Olympio.

SPIX, Johann Baptist von \& MARTIUS, Carl Friedrich von. Viagem pelo Brasil 1817-1820. Trad. Lúcia Furquins Lahaneyer $3^{\mathrm{a}}$ ed. São Paulo: Melhoramentos/ Brasília: Instituto Nacional do Livro, 3 vols, 1976.

STAROBINSKI, Jean. 1789: os emblemas da razão. Trad. Maria Lucia Machado. São Paulo: Companhia das Letras, 1988.

VARELA, Alex Gonçalves. A trajetória do ilustrado Manuel Ferreira da Câmara em sua "fase européia"(1783-1800), Revista Tempo, Niterói, vol. 12, n. 23, 2007.

\section{Resumo}

Neste artigo pretendemos estudar as cerimônias de aclamação do rei D. João VI ocorridas em Tejuco em 1818. A decodificação do rico arsenal de figurações estéticas encontradas naquelas celebrações pode se constituir em estratégia privilegiada para o entendimento da criação, naquele momento, de mitos que dariam sustentação e direção aos objetivos de afirmação do prestígio político 


\section{José Carlos Barreiro}

do rei e de consolidação de seu domínio sobre aquela região e sobre todo o território brasileiro. Exploraremos aqui sobretudo o conflito de memórias entre os significados simbólicos das celebrações ocorridas em Minas e a revolta da população contra a exploração colonial portuguesa ocorrida cerca de três décadas antes na região.

Palavras-chave: D. João VI; cerimônias de aclamação; mitos e memórias; domínio e território; Estado-Nação no Brasil; mitos e significações simbólicas.

\section{Abstract}

In this article we want to study the ceremonies of acclamation of king John VI that took place in Tejuco in 1818. The decoding of the rich array of aesthetic images found in those celebrations may be a privileged strategy to the understand of the creation, at that moment, of the myths that would support and direct the affirmation of the political prestige of the king and the consolidation of his domain on the region and on the whole Brazilian territory. We will explore here especially the conflict of memories between the symbolic meanings of the celebrations that occurred in Minas and the revolt of the people against the Portuguese colonial exploitation that had occurred about three decades before in the region.

Key words: King John VI; ceremonies of acclamation; myths and memories; domination and territory; State-Nation in Brazil; myths and symbolic meanings.

\section{Résumé}

Dans cet article on examinera les cérémonies d'acclamation du roi D. João VI qui ont eu lieu à Tejuco en 1818. Le décodage de la riche variété d'images esthétiques présente dans ces célébrations peut être une stratégie privilégiée pour comprendre la création, à ce moment-là, des mythes qui donneraient soutien et orientation au projet d'affirmation du prestige politique du roi et à la consolidation de sa domination sur la région et sur tout le territoire brésilien. On analysera en particulier le conflit de mémoires entre la signification symbolique de la célébration et la révolte du peuple de Minas contre l'exploitation coloniale portugaise qui avait éclaté dans la région environ trois décennies avant.

Mots-clés: D. João VI; cérémonies d'acclamation; mythes e mémoires; domaine et territorie; l'Etat-Nation au Brésil; mythes et signification symbolique. 